\title{
Differences in Chemical Learning Outcomes That are Teached with Problem Based Learning and Discovery Learning Using Lab Real Media on Subject of Solubility and Solubility Product
}

\author{
Gulmah Sugiharti ${ }^{1}$, Zurma Nilam ${ }^{2}$ \\ \{gulmahsugiharti@yahoo.com\} \\ Department of,Chemistry Education, Universitas Negeri Medan ${ }^{1,2}$
}

\begin{abstract}
This research is an experimental research that is able to find out whether there are differences in students' chemistry learning outcomes that teach with Problem Based Learning model (PBL) and Discovery Learning (DL) using Real Media Lab. In my experiments I was taught by PBL model with real lab and experiment II class with DL model using original lab. Data analysis uses two-t test. Expectation 1 class has an average pre and post test score of $51.5+7.27$ and $77.12+8.90$ with an average gain of 0.55 . The experimental class II has a pre-test average of $43.1+6.65$ and a post-test of $58.25+7.73$ with an average gain of 0.26 . Result of $t$ test at $\alpha=0,05$ obtained tcount $=$ $10,08>$ ttable $=2,0021$ hence alternative hypothesis accepted, and concluded there are difference of learning result which significant between student taught by PBL model and DL model that is equal to $26 \%$.
\end{abstract}

Keywords: Problem based learning (PBL); discovery learning (DL); real lab.

\section{Introduction}

The main problem of learning that is still widely found is about the low learning outcomes of students. It is known that the learning outcomes of high school / equivalent students are still low in terms of achieving the minimum completeness criteria (KKM), especially for MIPA subjects including Chemistry not meeting the KKM. This is indicated by the results of the TIMSS international study (Trends in International Mathematics and Science Study) about math and science achievements. The results of the average percentage of correct answers for Indonesian students in the 2011 TIMSS survey were: $31 \%$ for knowing, 23\% for applying and $17 \%$ for reasoning. The average is far below the average percent of true international answers, namely: 49\% for knowing, 39\% for applying, and 30\% for reasoning. The low percentage of knowing and applying domains shows that the ability to understand concepts and application of students in Indonesia is still low ${ }^{1)}$. With these achievements, Indonesian students are only able to recognize a number of basic facts but have not been able communicate and link various science topics, furthermore to apply complex and abstract concepts. One of the chemical subjects that some of the concepts are conceptual, and abstracts are solubility material and solubility results $(\mathrm{Ksp}){ }^{2)}$ (Devetak et all, 2007). Some research shows that some students have difficulties in learning this material. Onder and Geban $(2006)^{3)}$ 
state that students have difficulty understanding the dynamic state after the equilibrium of the solution is reached and solving the Ksp questions

Jahro, I dan Susilawati $(2008)^{4)}$ writes that chemistry learning cannot be learned only through reading, writing or listening. Chemistry learning is directed at the scientific approach where science process skills are carried out through experiments to prove a truth so that based on experience directly shapes the concepts, principles and underlying theories (Octaviany, $2014)^{5}$. Studying chemistry is not only mastering a collection of knowledge in the form of facts, concepts, principles, but also a process of discovery and mastery of procedures or scientific methods. In chemistry it is recognized the need to link theory and practice. What is found in practical experience needs to be found in the theoretical basis, so that the relationship between theory and practice can be mutually studied. One media that can be used to convey chemistry learning is real (real) media such as laboratory activities. Sugiharti, G. $\left.(2018)^{6}\right)$ found that students who are taught using the media get higher learning outcomes compared to students taught without using the media. To create the chemistry learning mentioned above, a learning model is needed. The results of the research by Sugiharti, G and Kholilah (2017) ${ }^{77}$. found that there was an influence of the learning model with student learning outcomes. Problem Based Learning (PBL) learning models and Discovery Learning (DL) can be an alternative in chemistry learning. The results of the research by Sugiharti, G and Habeahan, B $(2018)^{8)}$ also show that students taught with PBL models using virtual media get higher learning outcomes compared to students taught with PBL models using real lab media on thermochemical materials. Likewise Sugiharti, G and Limbong E.R $(2018)^{9)}$, found that there was an influence of the learning model using media on student learning outcomes, where PBL models with virtual media provided higher learning outcomes than PBL models with real media on Acid Bases.

Whereas the DL model, examined by Balim. A,G $(2009)^{10)}$ found that there are differences in learning outcomes between experimental groups taught with DL and control groups taught conventionally, in line with that Donuk, D $(2016)^{11)}$ said that conventional learning processes have turned to learning independently through discovery learning or DL models.

The existence of differences in the learning model raises the hypothesis, are there significant differences in the results of students' chemistry learning that are taught with PBL learning models with DL models on the subject of solubility and solubility results.

\section{Research Methodology}

This research was carried out at SMA Negeri $1 \mathrm{Tj}$. Pura, with a population of all students of class XI Science consisting of 4 classes, and the samples were taken randomly in 2 classes.

The design of this study uses the design of True Experiment Design which involves two classes, namely the first class applying PBL learning model with real media lab, the second class DL model with real media lab. The design form used is Pretest-Posttest Control Group Design. 
Table 1. Tabel 1. Pretest-Posttest Control Group Design

\begin{tabular}{cccc}
\hline Class & (Pre-Test) & Treatment & (Post-Test) \\
\hline Experiment I (PBL) & $\mathrm{T}_{1}$ & $\mathrm{X}_{1}$ & $\mathrm{~T}_{3}$ \\
Experiment II (DL) & $\mathrm{T}_{2}$ & $\mathrm{X}_{2}$ & $\mathrm{~T}_{4}$ \\
\hline
\end{tabular}

While testing the hypothesis, using the t-test formula (two-party test), namely the average test of two classes of samples with t-test at alpha 0.05 .

\section{Result And Discussion}

Table 2. Result of Average Pretest and Posttest.

\begin{tabular}{ccccccc}
\hline \multirow{2}{*}{ Class } & \multicolumn{5}{c}{ Type of Data } \\
\cline { 2 - 7 } & $\bar{X}$ & $\mathrm{~S}$ & $\mathrm{~S}^{2}$ & $\bar{X}$ & $\mathrm{~S}$ & $\mathrm{~S}^{2}$ \\
\cline { 2 - 7 } & 51,5 & 7,27 & 52,82 & 77,12 & 8,90 & 79,2 \\
\hline Experiment I & 51,5 Postest \\
Experiment II & 43,1 & 6,65 & 44,23 & 58,25 & 7,73 & 59,74 \\
\hline
\end{tabular}

$\bar{X}=$ Average value; $\mathrm{S}=$ Deviation $; \mathrm{S} 2=$ Varians

51.5 and the experimental class II was 43.1 and the average post-test experimental class I was 77.12 and the experimental class 58.25 which could illustrated through the diagram below. Based on the results of data processing, the average pre-test for experimental class I was.

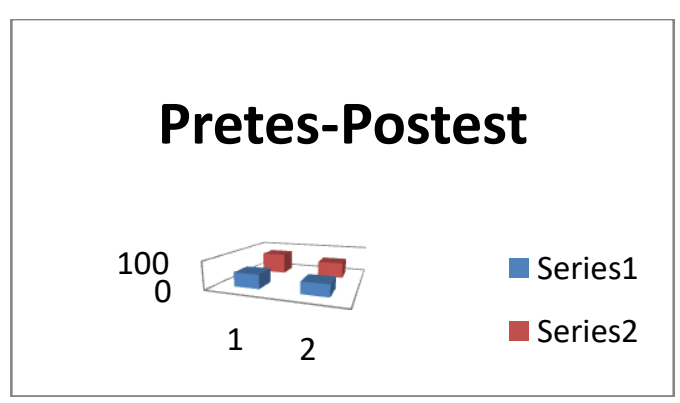

Fig. 1. Results of Sample Pretest and Posttest Results Diagrams

While the results of the $t$ test obtained t table $=2.0$ and tcount $=10.08$ at alpha 0.05 so that $t$ count was in the critical area that is reject Ho with -tcount <-2.021 and tcount $>2.021$. Thus Ho is rejected, $\mathrm{Ha}$ is accepted. Means: There are differences in students' chemistry learning outcomes that are taught using PBL models with the chemistry learning outcomes of students who are taught using the DL model on solubility and solubility results. This is in line 
with the results of the research by Sugiharti, G, et all $(2017)^{12)}$ that the PBL model provides better learning outcomes $(26.57 \pm 5.81)$ than the Direct Instruction model $(24.04 \pm 2.86)$

From the results of this study it can be said that learning with PBL models get higher learning outcomes than learning with DL models. This is in accordance with Gallagher's view, $(1995)^{13)}$ that PBL is a good alternative to improve understanding of chemical concepts. This learning involves students in an active, collaborative, student-centered learning process, which develops problem-solving abilities and independent learning abilities.

Problem-based learning is a learning solution designed to improve learning by bringing, delivering, requiring students to learn the content of teaching materials when solving problems. This is in line with Jonassen DH's opinion, (2011) ${ }^{14)}$ that "Problem Based Learning is an instructional strategy. is, it is an instructional solution designed to improve learning by requring studies to learn content while solving problems. This problem-based learning according to Smith's opinion cited by Amir. M.T(2009) ${ }^{15)}$ explained that PBL can be useful for: improving problem solving skills, easier to remember, increasing understanding, increasing knowledge relevant to the world of practice, encouraging them full of thought, building leadership and collaboration skills, learning skills and motivating learners. Finally, this study concluded that there were significant differences in students' learning outcomes between those taught with the PBL model and those taught with the DL model on the subject matter of the solution and solubility results. This study found that in teaching subjects the solution and solubility results are better taught using PBL models than the DL model.

\section{References}

[1] TIMSS dan PIRLS. (2016, Februari 12) Hasil Pemetaan [Online]. Available: http://timss.bc.edu. 2011.

[1] Devetak, I., Vogrinc, J., Glazar, S.A..Assessing 16-Years-Old students' Understanding of Aqueous Solution at Submicroscopic Level. Research Science Education, 2017.

[1] Onder, I. \& Geban, O., "The Effect of Conceptual Change Texts Oriented Instruction on Students' Understanding of The Solubility Equilibrium Concept", Journal of Education., vol. 8, no. 30 .

[1] Jahro, I. S \& Susilawati, Analisis Penerapan Metode Praktikum Pada Pembelajaran Ilmu Kimia di Sekolah Menengah Atas.Jurnal Pendidikan Kimia. Volume 1 nomor 1 edisi April 2008, Program Studi Magister Pendidikan Kimia, Program Pascasarjana: Universitas Negeri Medan, 2008.

[1] Octaviany, M., "Pengaruh Model Pembelajaran Problem Based Learning Dan Inquiry Terhadap Prestasi Belajar Siswa Ditinjau Dari Kreativitas Verbal Pada Materi Hukum Dasar Kimia Kelas X SMAN 1 Boyolali Tahun Pelajaran 2013/2014", Jurnal Pendidikan Kimia., Universitas Sebelas Maret. Surakarta, 2014.

[1] R Sugiharti, G. "Improve Outcomes Study subjects Chemistry Teaching and Learning Strategies through independent study with the help of computer-based media". ICIESC-2017 IOP Publishing IOP Conf. Series: Journal of Physics: Conf. Series 970 (2018) 011001 https://www.researchgate.net/publication/324136800 doi :10.1088/1742-6596/970/1/011001

[1] Sugiharti, G., and Hasibuan, S. K.. "The Effect of Inquiry Learning Method by Using Laboratory and Logical Thinking on Learning Outcome in Chemical Reaction Rate" Jurnal Pendidikan Kimia (JPKim),2017. vol. 9, no.4, 229-235.

https://doi.org/10.24114/ipkim. v9i1.6184.-1.

[1] Sugiharti, G. and Habeahan, Bastian J.W. Influence of Learning Model Using Laboratory and Numeric Ability to Student Learning Result on Thermochemical Material. International Education Studies doi:10.5539/. Vol. 11, No. 5; ISSN 1913-9020 E-ISSN 1913-9039 Published by Canadian Center of Science and Education, 2018. 
[1] Sugiharti, G and Limbong, E.R. Application of learning model with virtual lab and motivation in learning chemistry. Jurnal Pendidikan Kimia vol. 10 362-365,

doi: https://doi.org/10.24114/jpkim. v10i1.9676. Jurnal Pendidikan Kimia (JP Kim). 2018; e-ISSN : 2549-3116. p-ISSN :2085-3653, 2018

[1] Balım, A., G. "The Effects of Discovery Learning on Students' Success and Inquiry Learning Skills. Egitim Arastirmalari”-Eurasian Journal of Educational Research.,vol 35, pp. 1-20. 2009

[1] Dönük, D. "Revisiting language learning through the self: Discovery learning in the $21 \mathrm{st}$ century". Turkish Online Journal of English Language Teaching (TOJELT), vol.1 no.2, 66-74, 2016.

[1] Sugiharti, G., Mukhtar ; Abdul Hamid.. "The Effect of Learning Model and Mathematical Ability into Student's Learning Outcomes in Evaluation Course of Chemistry Education State University of Medan", Procceding of The 2nd Annual Internatioanal Seminar on Transformative Education and Educational Leadership (AISTEEL) 2017 Grand Mercure Hotel, October 16-17, 2017. http://www.atlantis-press/Proceeding/aisteel-17/articles.

[1] Gallagher, S, Stepien, W.J. Sher, B.T. Workman, Implementing Problem-Based Learning in Science Classrooms, School Science and Mathematics,: 95(3),pp. 136-146, 1995.

[1] D.A. Jonassen, Learning to Solve Problems, A Handbook for Designing Problem Solving Learning Environment, New York : Routledge, 2011.

[1] Amir MT., Inovasi Pendidikan Melalui Problem Based Learning. Jakarta: Kencana Pranada Media Group, 2009. 